\title{
Implementation Principles of the Religious Component in the Russian Educational System: Approaches and Solutions
}

\section{Principios de implementación del componente religioso en el sistema educativo ruso: enfoques y soluciones}

\author{
Tatyana N. Ivanova \\ Togliatti State University, Russia \\ ORCID: https://orcid.org/0000-0002-3806-171X \\ Aygul Z. Ibatova \\ Tyumen Industrial University, Russia \\ ORCID: http://orcid.org/0000-0003-0565-8533 \\ Rustem Adamovich Shichiyakh \\ Kuban State Agrarian University named after I.T. Trubilin, Krasnodar, Russia \\ ORCID: http://orcid.org/0000-0002-5159-4350 \\ Anatoly V. Kurochkin \\ Kazan Federal University, Russia \\ ORCID: https://orcid.org/0000-0001-9534-7637
}

Received 02-12-20 Revised 02-25-20 Accepted 06-13-20 On line 06-29-20

*Correspondence

Email: uni.state-2019@yandex.ru
Cite as:

Ivanova, T.N., Ibatova, A.Z., Shichiyakh, R.A., Kurochkin, A.V. (2020). Implementation Principles of the Religious Component in the Russian Educational System: Approaches and Solutions. Propósitos y Representaciones, 8 (SPE2), e650. Doi: http://dx.doi.org/10.20511/pyr2020.v8nSPE2.650 


\section{Summary}

An active discussion of the questions of the advisability of forming new principles of national unity and creating an orderly harmonious world in the minds of people, strengthening the educational functions of the state, its concern for public morality do not primarily concern education, humanization of its content, and revision of the educational process. The formation and implementation of a state policy adequate to this problem must comply with the requirements of our time, create, on the one hand, conditions for ensuring the rights and freedoms of citizens, including the observance of the fundamental principles of religious freedom, and on the other, develop legislative norms that regulate these rights. A legal democratic state provides for the formation of public policy in accordance with the needs of society and taking into account public thought. The secular nature of public education is not an obstacle to the introduction of disciplines in the provision of religious knowledge in the educational process of schools, religious knowledge can and should be considered as an element of secular culture. Knowledge of religion should be carried out by secular teachers, be neutral in content and not be accompanied by religious rites. The problems of the formation of moral and spiritual values, the worldview of a person, the introduction of religious disciplines in secondary schools are vividly discussed in scientific, educational, government circles, as well as among representatives of the clergy. The religious component in secular education will give importance to folk culture and traditional religion, which will form concepts such as tolerance and respect for other faiths and cultures, which is important in the context of globalization of the world.

Keywords: Religion; School Education; Spiritual Ethics; Religious Education; Religious Morality; Traditional Religion.

\section{Resumen}

Una discusión activa de las cuestiones de la conveniencia de formar nuevos principios de unidad nacional y crear un mundo ordenado y armonioso en la mente de las personas, fortaleciendo las funciones educativas del estado, su preocupación por la moral pública no se refiere principalmente a la educación, la humanización de su contenido y revisión del proceso educativo. La formación e implementación de una política estatal adecuada a este problema debe cumplir con los requisitos de nuestro tiempo, crear, por un lado, condiciones para garantizar los derechos y libertades de los ciudadanos, incluida la observancia de los principios fundamentales de la libertad religiosa, y por otro, desarrollar normas legislativas que regulen estos derechos. Un estado democrático legal prevé la formación de políticas públicas de acuerdo con las necesidades de la sociedad y teniendo en cuenta el pensamiento público. La naturaleza secular de la educación pública no es un obstáculo para la introducción de disciplinas en la provisión de conocimiento religioso en el proceso educativo de las escuelas, el conocimiento religioso puede y debe ser considerado como un elemento de la cultura secular. El conocimiento de la religión debe ser llevado a cabo por maestros seculares, tener un contenido neutral y no estar acompañado de ritos religiosos. Los problemas de la formación de valores morales y espirituales, la visión del mundo de una persona, la introducción de disciplinas religiosas en las escuelas secundarias se discuten vívidamente en círculos científicos, educativos, gubernamentales, así como entre representantes del clero. El componente religioso en la educación secular dará importancia a la cultura popular y la religión tradicional, que formará conceptos como la tolerancia y el respeto por otras religiones y culturas, lo cual es importante en el contexto de la globalización del mundo..

Palabras clave: Religión; Educación escolar; Ética espiritual; Educación religiosa; Moral religiosa; Religión tradicional. 


\section{Introduction}

Reaching the national level of the problem of introducing religious disciplines in secondary schools requires studying and analyzing a whole range of issues to form open, understandable positions on the state's approach to regulating the religious component in the secular education system.

An active discussion of the questions of the advisability of forming new principles of national unity and creating an orderly harmonious world in the minds of people, strengthening the educational functions of the state, its concern for public morality do not primarily concern education, humanization of its content, and revision of the educational process. In this regard, the problems of the formation of moral and spiritual values, the worldview of a person, the introduction of religious disciplines in secondary schools are vividly debated in scientific, educational, government circles, as well as among representatives of the clergy.

Regarding the role played by the ROC, it is important to mention that the major initiator of RE in Russia was indeed the ROC. Since the collapse of communism leaders of the ROC have actively lobbied for the introduction of RE devoted to the history and teaching of Orthodox Christianity to attract new members from the Russian population. Since then various courses on religion, teaching mainly Orthodox Christianity, as well as Islam in predominantly Islamic regions, were taught in school on a local basis. However, this practice ended with the implementation of a new Federal Law on Education in 1992, which stated that education should be secular. This made the ROC to review its tactics towards the introduction of RE. The ROC renamed the subjects on Orthodox Christianity into the 'Basics of Orthodox Culture' (BOC) to avoid doubts concerning its secular character. Nevertheless, BOC still pursued the task of religious nurture. 2 Due to continuous pressure of ROC leaders, in some regions BOC even became a compulsory course as part of the flexible component within the national curriculum. In 1997, the influence of the ROC on education further increased with the adoption of the Federal Law on Freedom of Conscience and Religious Associations. Although this law again guaranteed the secular character of education, it also contained an interesting regulation on church-state relations in its Preamble. The Law (1997) recognises the special role of the ROC in '(...) the history of Russia, the formation and development of its spirituality and culture' as well as the importance of other religions like Islam, Buddhism or Judaism in Russian history. As a result, these four religions, with Christianity limited to Orthodox Christianity, were officially recognised as the 'traditional' religions of Russia and later became the 'confessional' modules within the current system of RE.

These legal developments resulted in a widespread fear of indoctrination by the ROC and led to heated debates among representatives of other confessions, politicians as well as educators. Also, Russian parents became concerned about the influence of the ROC on their children. This unrest initiated the next and final phase in the introduction of RE in the Russian educational system. To put an end to the diversity of local courses on religion, on 1 September 2012 it became a national requirement in Russia for fourth and fifth grade pupils (9-11 year olds) to learn about Fundamentals of Religious Cultures and Secular Ethics (FRCSE). The introduction of FRCSE was a compromise between the state and the ROC. The state wanted to introduce a nonconfessional RE course for all students on the history of religion or world religions, but such a course was rejected by the ROC authorities as it might educate children into moral relativism and indifference (Chaplin, 2008). However, confessional RE provided and funded by the state is against the Law and the Constitution. Therefore, the state and the ROC reached the compromise that RE, i.e. FRCSE, consists of six optional modules from which parents have to choose only one for their children to attend. Next to four modules concerning the aforementioned traditional religions of Russia, parents can also opt for a module on world religions or for a secular module on ethics. 
Today, RE in Russia thus is a compulsory subject called FRCSE. FRCSE is a compromise and, as the above account of its genesis shows, it is certainly not uncontested. In view of its history and current practice, several critical questions emerge like: What is the influence of the ROC on FRCSE? Is Orthodox Christianity a dominant focus of FRCSE? What is the interest of the Russian state in FRCSE and what goal does the state pursue with the help of FRCSE? Is FRSCE as a Russian model of RE completely different from RE in European countries? and which characteristics of FRSCE might be considered distinctive compared to European models of RE? By addressing questions like these, we aim to give a critical account of the recent developments regarding RE in Russia. In order to do this, we will compare this Russian model of RE with several European models of RE with the help of a framework consisting of three categories we partly derived from the work of Schreiner (2001a):

1. Responsibility for RE: Is RE the responsibility of the state or of religious organisations? Is there a close cooperation between the state and religious organisations concerning RE? Do specific religious organisations have privileges with respect to RE? Who is responsible for providing syllabi for RE? Is RE a subject of inspection like other school subjects or is it exempt from inspection?

2. Place of RE in the curriculum and/or in the educational system: is RE a timetabled school subject at primary and/or secondary school or is it taught as part of the content of other school subjects? Is it compulsory or not? Is there a possibility to opt out?

3. Content and aim of RE: is RE based on a confessional, theological approach or on a religious studies approach? Does it aim at the transmission of a specific faith tradition (education into religion), on the transmission of basic knowledge about religion (education about religion) or on the spiritual development of students (education from religion)? Is RE integrative (designed for all students) or separative (students are divided into different confessional groups)? Does RE foster the development of pupils as independent individuals with their own views of life or does it rather focus on the formation of a specific identity?

By comparing the Russian model of RE, or FRSCE, to different European models of RE we aim to come to a better understanding of what is currently going on in Russia. In order to do this, we will compare the Russian model of RE with the models of RE in Sweden, Denmark and England. We deliberately choose these latter countries, because these countries are all familiar with the system of a state church. In our opinion, this makes them an excellent reference material for the Russian situation in which the relationship between the state and the Russian Orthodox Church again is almost taking the form of a state church.

In Sweden the state has direct supervision over RE. The national objectives and guidelines for RE are laid down by the Government, while the National Agency for Education (Skolverket) has a supervisory role to ensure that the Education Act is being complied with (Johansson, 2008, p, 374). The Church of Sweden, even though it was a state church until 2000, has no special privileges on school matters nor on RE. In contrast, the Danish model of RE is strongly characterised by the fact of having a state church; i.e. the Evangelical-Lutheran Church of Denmark (Folkekirken). In terms of responsibility, RE in Denmark is non-confessional as it is delivered and provided by the state and not the Church. However, the content of RE, which is called 'Kristendomskundskab' ('Christian knowledge') in Denmark, still strongly emphasises Evangelical-Lutheran Christianity. In addition, the state church has the privilege of a confirmation year at seventh or eighth grade (age 13-14) when there is no regular RE and most pupils attend an out-of-school confirmation programme led by a local Lutheran minister (Jensen and Kjeldsen, 2013, p. 190).

As mentioned already, as in Sweden the state also has direct supervision over RE in Denmark. However, Danish schools are somewhat more autonomous than Swedish schools. The Ministry of Children and Education issues the normative objectives for school learning including subject targets and central knowledge areas (Jensen 2013, 32). In order to set targets and knowledge areas for RE the Ministry appoints an expert committee of scholars of religions, 
theologians and RE teachers with no religious organisations being formally involved in the process. Nevertheless, recent committees were headed by a minister or even a bishop from the Danish Church (Jensen 2013, p. 33). After the national objectives have been issued LEAs (municipal councils) are free to make their own local curricula in accordance with the national objectives and guidelines. Schools thus can design their own RE syllabi as long as they follow the aforementioned guidelines.

In terms of state responsibility for RE, the English model differs from the Swedish and Danish models as state responsibility over RE is more indirect in England. RE is part of the basic curriculum and not the national curriculum. This gives RE the same status as other school subjects of the National Curriculum, but it does not comply with the nationally prescribed Attainment Targets, Programmes of Study and Assessment Arrangements. This is the reason why RE is not taught according to a national syllabus, but according to a locally agreed syllabus. Local syllabi are designed by the Local Education Authorities (LEAs), which to this end form the Standing Advisory Conferences on RE (the SACREs). The SACREs consist of four groups: representatives of Christian and other religious denominations (reflecting the local religious composition); representatives of the Church of England; representatives of teachers associations and members of the authority itself. Thus, the close cooperation with religious organisations regarding RE is officially recognised. Finally, like any other school subject, RE is inspected in England by the Office of Standards in Education (OFSTED). 4 As regards the state church, the Church of England, it is given some privileges and the existence of a state church, of course, determines to some extent the content of RE, which should ' $(\ldots)$ reflect the fact that the religious traditions in Great Britain are in the main Christian' (Education Reform Act 1988, section 8. Still, this situation does not allow RE to be confessional as it is important to take into account other religious and non-religious views.

\section{Materials and Methods}

Analysis of publications of domestic scientists, in particular the works of Alontsev D.V., Gavrilov V.V., Danilova A.S., Kartashova M.M., Kireev M.N., Chernyavskaya N.E., Kireeva N.V., Knyazkova N.P., Kozlovtseva O.S., Kutikova N.A., Podvoisky L.Ya., Romankova L.N., Saklakova L.N., Starykh N.P., Sviridova V.V. and others are evidenced by a wide range of approaches to understanding the problem and, accordingly, to ways to solve it. There are no wellestablished interpretations of the concepts of "secular education" and "religious education", the category "separation of the school from the church" is interpreted differently. All this causes heated debate, making it difficult to determine the nature of relations between secular and religious in the system of general education.

Alontseva D.V., Gavrilova V.V., Kireev M.N., Chernyavskaya N.E., Kireeva N.V. They dealt with the pedagogical foundations of secular and religious education in the process of teaching in high school, as well as the issues of education of patriotism in modern Russian society.

Danilova A.S., Knyazkova N.P., Saklakova L.N. studied the experience of religious education of foreign countries, such as the UK, USA, Germany. Their work served as an important basis for building the structure of the article and determining the scientific research methodology.

Kartashova M.M., Romankova L.N., Starykh N.P., Sviridova V.V., Podvoisky L.Ya., Kozlovtseva O.S., Kutikova N.A., examined issues of spiritual and moral education in historical measurement. The results of their research allow using the experience of the past on the use of religious education in the modern school.

The main research methods are determined by its specificity. The content analysis method allowed us to analyze the relevant literature on this topic. The structural analysis method identified 
the most important aspects of religious education in the school. The problems of using the experience of foreign countries allowed to solve the comparative method. The historical method has determined the possibility of using Russia's own experience in modern spiritual and moral education at school.

\section{Results}

The formation and implementation of a state policy adequate to this problem must comply with the requirements of our time, create, on the one hand, conditions for ensuring the rights and freedoms of citizens, including the observance of the fundamental principles of religious freedom, and on the other, develop legislative norms that regulate these rights.

Clarification of a number of issues, the review of which is proposed in the article, is necessary when substantiating a policy to regulate the relationship of secular and religious in the general education system, the implementation of whichto obey the outcome of the need to maintain harmony and stability in society, the formation of interfaith tolerance, minimizing negative trends in society, including in the religious environment. Therefore, the solution of these issues, the development of optimal recommendations is a strategically important task aimed at protecting national interests and ensuring domestic political security. "Today the world pedagogical science agrees that true education should be deeply national in content and character. Various signs of psychology, mentality, intelligence of each cultural and historical community of people should be taken into account when organizing the educational process. This refers to its enrichment with its original content, means, methods of educational influence, which have been formed in every ethnic group over the centuries and have become an integral part of its culture. After all, national education is the basis of the cultural and historical development of any nation, and consequently, of the individual" (Romankova, 2015).

Awareness of government positions on this issue requires analysis and consideration of the following issues: 1) a clear understanding of the essence of the categories "secularism", "secular nature of education", "separation of the school from the church"; 2) the definition of the boundaries of the religious component in a secular school; 3) public perception of the problem; 4) analysis of the experience of Western countries, taking into account the provisions of international legal acts. The introduction of the term "secularism" as a noun is associated with French practice, when at the end of the 19th century it was used as a sign of a state that positioned itself independent of the clergy, neutral in its relation to all cults and free of any theological concept. The term was used only as an adjective in the phrases "secular school", "secular morality", "Secular state". The French scientist J. Borera complements this characteristic with the thesis that the state ensures full equality of citizens in matters of faith and complete freedom of conscience through the simultaneous rejection of state atheism and has become its theological concept (Alontseva, 2019; Gavrilova, 2017).

The general definition of the terms "secular", "secular" in modern Russian explanatory dictionaries can be reduced to an understanding of state institutions as such, reflecting their general civic, secular orientation, and in relation to a person as such, which does not have a spiritual dignity (Danilova, 2017). "Religion is not necessarily something complete and completed, given as a known achievement in a worldview or in life. It eternally flows and creates, attracts and strives ... This is the principle of creative fluidity of pure religious experience. Hence: the question of religious education is the question of the religious construction of the roots of religious life, instinct and passion, chaos, which is rooted in dogma, and not just this construction of complete forms of religious thought and life. The affective and instinctive root of religious myth, image and dogma under its intellectual shell” (Podvoisky \& Losev, 2018).

Thus, the terminological significance of the secular nature of education does not in itself mean a ban on obtaining religious knowledge in a comprehensive school. The problem is not 
whether it is "possible" or "not possible" to introduce religious disciplines at school, but in understanding the difference between "religious" and "providing religious knowledge".

However, there are certain restrictions for the religious component in a secular school. In different countries they are different and are determined by a specific model of state-church relations and, accordingly, by national legislative acts.

On the forms of providing religious knowledge, the opinions of scholars as a whole coincide on the expediency of the cultural, ethical orientation of religious educational disciplines. It is worth agreeing with the three main forms of providing religious knowledge that are described by Russian researcher I. Ponkin (Kartashova, 2017). He characterizes religious and cultural education as a purposeful process of acquiring knowledge about a specific religious creed, culture and life of a particular religion.

Religious education is associated with the teaching of the comparative aspect of knowledge about existing creeds, their features, practice, key events and historically significant individuals, the historical, political and socio-cultural role of religion as a phenomenon of social life. "It was in the bowels of the Orthodox culture in Russia that the basic spiritual and moral values were formed and passed down from generation to generation: virtue, collegiality, piety, selflessness, conscience, industriousness, love for the Fatherland (Knyazkova, 2009; Saklakova, 2014). Spiritual and moral education forms the core of the personality, having a beneficial effect on all aspects and forms of a person's relationship with the world: on his ethical and aesthetic development, worldview and civic formation, patriotic and family orientation, intellectual potential, emotional state and general physical and mental development" (Kutikova, 2017). on the basis of this, a mixed form of education is presented as a combination of religious-cultural and religious studies-ethnoconfessional education, along with religious knowledge and the training of students in the spiritual and moral values and culture of traditional religion as an integral part of national culture (Knyazkova, 2008).

A legal democratic state provides for the formation of public policy in accordance with the needs of society and taking into account public thought. So, the decision to introduce disciplines for the provision of religious knowledge in secondary schools should be supported by a positive attitude of citizens. After all, issues relating to religion and the church do not go unnoticed by sociological services. "The moral principle laid down in the historical past of our country is the basis of the spiritual and moral education of modern pedagogy. Moral education has always been a means of personality formation. And periods of weakening attention to the formation of moral qualities of citizens inevitably led to a weakening of the position of the state. The issues of Orthodox education in combination with secular education, which, according to the author, was based on the development of habits of correct behavior, based on their moral principles, remain relevant today. At present, during the period of the spiritual and moral revival of Russia, the problem of integrating secular and Orthodox approaches to the formation of a spiritual and moral personality is encouraging scientists and educators to search for new forms and methods, as well as to turn to the accumulated millennial experience of Russian pedagogy" (Kireev et al., 2012).

The experience of solving the problem by Western democracies can be useful for Russia as well. It should be noted that the right to study religion is enshrined in most constitutions of Western countries, it is part of the right to education in accordance with the national cultural identity of a person. As noted by Alontseva D.V. The right to study religion in Western European countries includes the right to establish private schools controlled by a particular church, and the right to study religion in public schools. In some countries, religious education in public schools is the norm of the constitution (Germany, Italy, Spain, Poland, the Czech Republic), in others it is not prohibited, but it is not introduced constitutionally and is regulated by law. Relations 
between the authorities and denominational schools may be of a contractual nature (France, Spain) in some countries denominational schools are granted public status (Germany, Austria, Switzerland, Slovakia). "The state, unlike the church, is characterized by three components power, population, territory. Both institutions are different not only in their organizational essence, but also in their goals and means of achieving these goals. The state has a coercive apparatus, the church has religious and moral means that influence the spiritual consciousness of the population. The main goal of the designated public institutions is the consolidation of society, the support of its moral principles on the basis of universal values. Throughout the development and interaction of religious institutions and political structures, the relationship between them was of different forms: papocaesarism, caesarepapism, "a symphony of authorities"' (Alontseva, 2019).

As a rule, denominational schools in Western countries, to one degree or another, enjoy financial support from the state. Such funding may include staff costs and the cost of textbooks when the school is granted public status. In other cases, the state provides free training in part of the curriculum, carried out according to state standards.

Thus, the approach of the western region is characterized by an orientation toward the obligatory participation of the state school in religious education and upbringing, the presence of compulsory religious disciplines in it, the aim of which should be, first of all, to educate the religiosity of children and bring them to church. "In a broad sense, the goal of spiritual and moral education is the development of high spirituality in society, the formation of citizens with positive values and qualities that can manifest them in a creative process in the interests of the homeland. Through spiritual and moral education moral feelings are formed, such as responsibility, patriotism, duty; a moral position is determined in solving issues of various scales, the formation and development of the ability to distinguish between good and evil is underway, conditions are created for the manifestation of goodwill in solving universal human problems" (Kozlovtseva, 2017).

They are positive in this region and in the accompaniment of lessons by prayers and other elements of religious rites. In the second regions, the situation is the opposite. There are many supporters of providing religious education and upbringing outside the public school. If a state school is involved in religious education and training, confidence in ensuring voluntary study of religious disciplines prevails. The purpose of their implementation is considered, first of all, to study the history of religion and moral commandments, which contain various creeds, without raising the religiosity of children and attracting them to the church, as well as without accompanying training with prayers and other elements of religious rites.

The worldview of the child is formed both by ideal, cultural ideas, and ideas about material reality. Understanding the line between cultural idealization (present in religion and art) and life reality (with which a person deals in practice) is the core of a rational, adequate worldview.

If cultural ideas begin to supplant ideas of reality, then a person is deprived of the ability to act adequately in the real world: the surrounding reality is replaced in his mind with an ideal picture of the cultural world. There can be nothing "just like that" in education. Even a trip to a park, museum or theater serves the purpose of learning - a child is taught to perceive the aesthetics of nature and the aesthetics of art, to see their common and their difference, to understand the connection between one and the other.

If he does not learn this, he will be deprived of something very important in life. Familiarization with religion should teach the child the perception of different religions in the context of a multifaceted world culture, art, a person's connection with nature and with his very difficult history. The creation of such a course in religious studies is the most difficult task of laying the foundation for mutual understanding of people with completely different outlooks on life. A person with such a wealth of knowledge about religions can always look at his life, at his 
actions and motives from different angles, including from the position of any other person with whom his fate will reduce.

Most researchers share the view that a comprehensive school should give students along with materialistically oriented knowledge religious knowledge as an alternative to a materialistic view of the world (Kozlovtseva, 2017).

\section{Conclusion}

Thus, religious education in the school must be implemented taking into account the following principles:

1. The secular nature of public education is not an obstacle to the introduction of disciplines in the provision of religious knowledge into the educational process, religious knowledge can and should be considered as an element of secular culture (Vakhitov et al., 2017).

2. Knowledge of religion should be carried out by secular teachers, be neutral in content and not be accompanied by religious rites.

3. The introduction of religious disciplines in general corresponds to public sentiments, however, the attitude of citizens towards such disciplines has significant regional differences.

4. Most Western countries, to one degree or another, support the provision of religious knowledge in secondary schools, as well as ensure the creation and functioning of general educational confessional educational institutions, established by religious organizations. For the basing of state policy on these provisions, the practice of interaction between "secular" and "religious" in the general education system of Russia may be as follows: the presence in the state educational institutions of disciplines that provide religious knowledge; the existence of general educational confessional educational institutions that provide general education according to state standards, as well as confessional-oriented education and training of a general educational character (Starykh \& Sviridova, 2017).

This practice will require such government steps:

- inclusion in the invariant part of the basic curriculum for secondary schools of religious disciplines;

appropriate form of training - mixed (a combination of religious-cultural and religious education) compulsory subjects for study at school, voluntariness - for students to study;

- ensuring the principle of voluntary choice of disciplines for the provision of religious knowledge by the presence of alternative subjects of a moral and ethical direction;

- granting to local authorities the right to determine the variable part of the religious disciplines of educational institutions, taking into account regional confessional and social characteristics;

- training of the relevant cadre of secular teachers

religious items;

- legislative support for the possibility for religious organizations to establish general educational institutions according to state standards, their licensing and accreditation by relevant state authorities on a common basis;

- development of mechanisms of state financial support for general educational confessional educational institutions.

\section{References}

Alontseva, D.V. (2019). Church and State in the Catholic Tradition: A Dominant Model of Relationship. Bulletin of the Southwestern State University. Series: History and Law, 9(30), 16-23. 
Danilova, A.S. (2017). Religious education in private boarding schools in the UK as the most traditional type of education. Bulletin of Kostroma State University. Series: Pedagogy. Psychology. Sociokinetics, 23(1), 217-220.

Gavrilova, V.V. (2017). The education of patriotism in modern Russian society. Integrative perspective in the humanities, 1, 72-77.

Gavrilova, V.V. (2016). About patriotic education, religious factor and education. Problems of Civil Unity of the Russian Nation. Materials for the Interregional Scientific and Practical Conference-Dialogue. Executive Editor M.G. Pismanik, 207-214.

Kartashova, M.M. (2017). Reflections on education in the context of understanding the cultural and historical experience of the people. News of the Voronezh State Pedagogical University, 2(275), 38-41

Kireev, M.N., Chernyavskaya, N.E., \& Kireeva, N.V. (2012). Pedagogical foundations of secular and religious education in the learning process. Scientific potential, 2, 41-46.

Knyazkova, N.P. (2008). Confessional-religious education in German schools: historical and pedagogical aspect. Family in Russia, 1, 118-124.

Knyazkova, N.P. (2009). The legal basis for the interaction of the family, school and the state in the religious education of students in a comprehensive school in Germany. Education World - Education in the World, 3(35), 63-68.

Kozlovtseva, O.S. (2017). Interrelation of spiritual, moral and environmental education in a modern school. IX Cyril and Methodius readings "Man in the space of Orthodox culture" is an inter-university collection of scientific and methodological articles,71-76.

Kutikova, N.A. (2017). Spiritual and moral education of schoolchildren in studying the foundations of Orthodox culture of the course "Foundations of religious cultures and secular ethics". ASOU Conference: a collection of scientific papers and materials of scientific and practical conferences, 1, 1119-1126.

Podvoisky, L.Ya., \& Losev, A.F. (2018). On religious and secular education and upbringing. Dmitriev Readings Materials of the III All-Russian Scientific Conference. Responsible editors E.G. Timofeeva, A.P. Glazkov, A.O. Tyurin, 100-104.

Romankova, L.N. (2015). Educational work in the context of national education systems. Innovative educational technologies, 3(43), 35-42.

Saklakova, L.N. (2014). The main approaches to religious education in secondary schools in the USA. Bulletin of the Volgograd State Pedagogical University, 1(86), 100-103.

Starykh, N.P., \& Sviridova, V.V. (2017). The role of religious education in modern schools. University in the global world: new status and mission collection of materials of the XI International Scientific Conference. Moscow State University named after M.V. Lomonosov, Faculty of Sociology, 839-841.

Vakhitov, R.R., Ildusovna, G.I., Rodionova, A.E., Stavruk, M.A., Ilyin, A.G., \& Ivanova, N.L. (2017). Teaching humanities at the university. Man in India, 97(20), 1-6. 